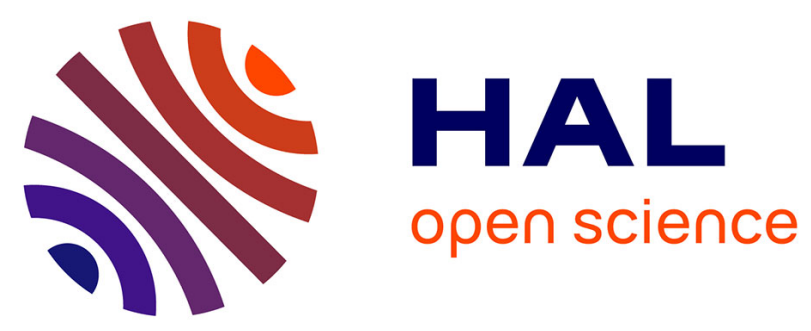

\title{
Life table of Tetranychus urticae (Koch) (Acari: Tetranycidae) on different Turkish eggplant cultivars under controlled conditions
}

Nabi Alper Kumral, Pinar Hephizli Göksel, Elif Aysan, Ayşenur Kolcu

\section{To cite this version:}

Nabi Alper Kumral, Pinar Hephizli Göksel, Elif Aysan, Ayşenur Kolcu. Life table of Tetranychus urticae (Koch) (Acari: Tetranycidae) on different Turkish eggplant cultivars under controlled conditions. Acarologia, 2018, 59 (1), pp.12-20. 10.24349/acarologia/20194307 . hal-01971718

\author{
HAL Id: hal-01971718 \\ https://hal.science/hal-01971718
}

Submitted on 7 Jan 2019

HAL is a multi-disciplinary open access archive for the deposit and dissemination of scientific research documents, whether they are published or not. The documents may come from teaching and research institutions in France or abroad, or from public or private research centers.
L'archive ouverte pluridisciplinaire HAL, est destinée au dépôt et à la diffusion de documents scientifiques de niveau recherche, publiés ou non, émanant des établissements d'enseignement et de recherche français ou étrangers, des laboratoires publics ou privés. 


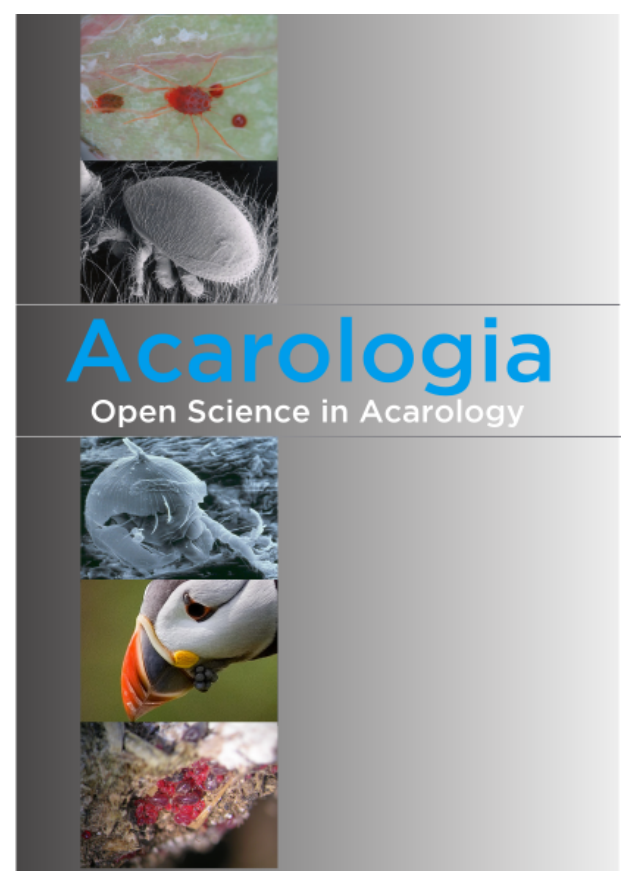

\section{Acarologia}

A quarterly journal of acarology, since 1959

Publishing on all aspects of the Acari

All information:

http://www1.montpellier.inra.fr/CBGP/acarologia/ acarologia@supagro.inra.fr

\section{OPEN ACCESS}

\section{Acarologia is proudly non-profit, with no page charges and free open access}

Please help us maintain this system by encouraging your institutes to subscribe to the print version of the journal and by sending us your high quality research on the Acari.

Subscriptions: Year 2019 (Volume 59): $450 €$ http://www1.montpellier.inra.fr/CBGP/acarologia/subscribe.php

Previous volumes (2010-2017): $250 €$ / year (4 issues)

Acarologia, CBGP, CS 30016, 34988 MONTFERRIER-sur-LEZ Cedex, France

The digitalization of Acarologia papers prior to 2000 was supported by Agropolis Fondation under the reference ID 1500-024 through the « Investissements d'avenir » programme

(Labex Agro: ANR-10-LABX-0001-01)
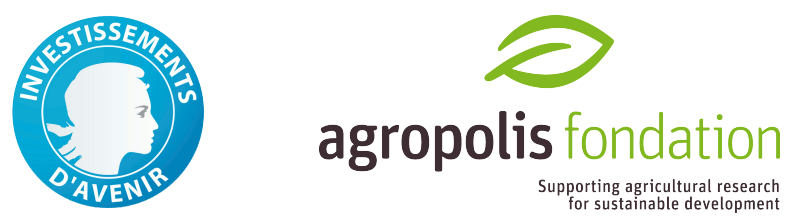

Acarologia is under free license and distributed under the terms of the

Creative Commons-BY-NC-ND which permits unrestricted non-commercial use, distribution, and reproduction in any medium, provided the original author and source are credited. 


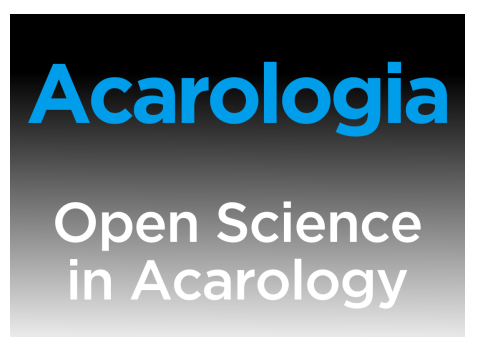

\section{Life table of Tetranychus urticae (Koch) (Acari: Tetranycidae) on different Turkish eggplant cultivars under controlled conditions}

\author{
Nabi Alper Kumral ${ }^{a}$, Pınar Hephızlı Göksel $^{b}$, Elif Aysan $^{a}$, Ayşenur Kolcu $^{a}$ \\ ${ }^{a}$ Department of Plant Protection, Faculty of Agriculture, Uludag University, Gorukle Campus, Bursa, \\ 16059, Turkey. \\ ${ }^{b}$ Ataturk Horticultural Central Research Institute, 77102, Yalova, Turkey.
}

\section{Original article}

\section{ABSTRACT}

The life table parameters of Tetranychus urticae were evaluated on 7 eggplant cultivars namely, Anamur, Aydin Siyahi, Balikesir 76, Kemer, Pala 49, Topan 374, Yalova Topan, in controlled laboratory conditions in daylight for 16 hours $27 \pm 1{ }^{\circ} \mathrm{C}$ temperature, $65 \%$ relative humidity. Assays were conducted on eggplant leaflets in Petri dishes. There was a significant difference in the durations of egg and juvenile development of T. urticae. However the survival rates of $T$. urticae were not significantly different on the tested eggplant cultivars. The values of the natural rate of increase, $r_{m},(0.218-0.269)$, net reproduction rate, $\mathrm{R}_{0},(26.74-45.51)$ and the mean generation time, $\mathrm{T},(13.31-15.45)$ significantly differed among eggplant cultivars. Notably, the shortest development duration as indicated by the lowest $r_{m}$ and $R_{0}$ values were observed on Pala 49 followed by Anamur and Balikesir 76 cultivars.

Keywords two-spotted spider mite; life table parameters; development; eggplant; cultivar

\section{Introduction}

More than thirty mite species have been identified on eggplants Solanum melongena L. (Solanaceae) around the world (Cobanoglu 1989, Grewal 1992, Kapoor et al. 1997, Singh \& Singh 1999, Kumral \& Kovanci 2005, Can \& Cobanoglu 2010, Ozsisli \& Cobanoglu 2011, Reddy et al. 2011, Kumral \& Cobanoglu 2016). Amongst them, Tetranychus urticae is a common eggplant pest (Grbic et al. 2011, Migeon \& Dorkeld 2016). Both red and green morphological forms of the spider mite are very harmful to Solanaceous (Soysal \& Yayla 1988, Grewal 1992, Kapoor et al. 1997, Brar et a.l 2003, Leite et al 2003, Kumral \& Kovanci 2005, Ozsisli \& Cobanoglu 2011, Can \& Cobanoglu 2010). During the production of eggplants, the mite causes high fruit losses due to it feeding on chlorophyll and pigments of eggplant leaves. These leaves, which have reduced assimilation and photosynthesis, are prone to desiccation and such effects lead to high product losses due to high water loss (Tomczyk \& Kropczynska 1985, Grewal 1992, Kapoor et al. 1997, Singh \& Singh 1999, Brar et al. 2003, Leite et al. 2003, Kumral \& Kovanci 2005).

For controlling the pest, the intensive use of pesticides leads to both decreasing natural enemy populations and increasing environmental pollution (Kumral \& Kovanci 2005, Simon 2014). When pesticides are used recurrently, the spider mite can develop resistance to some acaricides and insecticides (Van Leeuwen et al. 2010, Whalon et al. 2016). In recent years, as an alternative to pesticides, predator mites, phytoseiides, have been commercially produced and used for controlling T. urticae particullary in greenhouses (Moon et al. 2006, Stansly 
et al. 2009, Shibao et al. 2009, Kilincer et al. 2010). Instead of such a single application, combinated strategies "Integreated Pest Management" could increase successes of the mite control. Therefore, one of the most important components of the strategy is the use of pest resistant cultivars or lines of host plants. As an alternative to pesticides, the use of resistant eggplant varieties may help keep the damage below the economic damage level. Although eggplants are more preferred by T. urticae than other solanaceous plants (Van Den Boom et al. 2003, 2004), some cultivars of the plant can be less suitable for the mite (Khanamani et al. 2013). Similarly, preference, development and reproduction differences in T. urticae were shown in different cultivars of some Solanaceous plants (Zatyko \& Martinovich 1986, Hoy 2011, Atalay \& Kumral 2013, Keskin \& Kumral 2015). To date, the biology and life table parameters of T. urticae on the eggplant has been rarely investigated (Khanamani et al 2013) and biological performances of different Turkish eggplant cultivars have not been determined yet.

The host plant preference of any pest species can be exhibited by determining developmental duration and survival of its immature stages and oviposition and longevity of its mature stages (Sedaratian et al. 2011). In addition, some biodemographic parameters can show the population growth potential of any pest on its hostplant (Birch 1948). For this purpose, the development, survival and biodemographic parameters of T. urticae were determined on leaf-disc in Petri dishes on seven Turkish eggplant cultivars in controlling conditions during 2015-2017.

\section{Materials and methods}

\section{Eggplant cultivars and growth}

Seven common Turkish cultivars of eggplant (Solanum melongena L.) were used in this study, namely Anamur, Aydin Siyahi, Kemer, Topan 374 (Bursa Tohum, Turkey), Balikesir 76, Pala 49, Yalova Topan (Ataturk Horticultural Central Research Institute, Yalova, Turkey). The seeds of these cultivars were sown in a peat medium (Klasmann TS 1-Deilmann, Geeste, Germany). Three weeks after sowing, the seedlings were transplanted into $1.5-\mathrm{L}$ pots filled with peat and placed in a controlled growth room with a $16 \mathrm{~L}: 8 \mathrm{D}$ photoperiod at $27 \pm 1{ }^{\circ} \mathrm{C}, 65 \pm 5 \% \mathrm{RH}$. Seedlings were irrigiated every three days with tap water and fertilized weekly with $100 \mathrm{~mL}$ water soluble fertilizer containing [3\% total nitrogen, $7 \%$ phosphorus, $4.5 \%$ potassium, $0.1 \%$ sulphur, $0.25 \%$ iron, $0.01 \%$ copper, $0.1 \%$ zinc, $0.1 \%$ manganese, $0.01 \%$ Boron and $0.001 \%$ molybdenum] prepared by Uludag University, Department of Soil Science and Plant Nutrition (Bursa, Turkey). Four weeks after transplanting, five fully developed uniform plant leaves were used for experiments.

\section{Spider mite colony}

Mites Tetranychus urticae Koch (Acari: Tetranychidae), used in the experiment come from a mass culture maintained for at least 8 years on potted bean plants in our laboratory. The colony was mass reared in a climate-controlled growth room with a $16 \mathrm{~h} \mathrm{Light} \mathrm{(L):} 8 \mathrm{~h}$ Dark (D) photoperiod at $27 \pm 1{ }^{\circ} \mathrm{C}, 65 \pm 5 \% \mathrm{RH}$. Synchronous colonies of $T$. urticae were provided by rearing at least two generations on each experimental eggplant cultivar.

\section{Development and survival of developmental stages}

The leaf disc in Petri dish method described by Keskin \& Kumral (2015) was used. But the Petri dishes and eggplant leaflet have a larger diameter $(120 \mathrm{~mm})$ in our study. For mating, a female teliochrysalid and two males were placed onto each leaf disc. The leaf discs were placed inside an insectarium (Nüve, Ankara, Turkey) with a 16L:8D photoperiod at $27 \pm 1^{\circ} \mathrm{C}, 65 \pm 5 \% \mathrm{RH}$. After the fameles oviposited, both sex adults were removed from leaflets. The leaflets were checked twice a day in immature stages, and the duration and mortality of different immature 
stages were recorded using a stereomicroscope. The leaves were changed every week and mites were transferred to these fresh leaves. Non-hatched eggs and dead immatures were recorded to calculate survival rates.

\section{Oviposition and life table parameters}

After a new generation of females emerged, the durations of preoviposition, oviposition, postoviposition, the daily fecundity and longevity of each female were recorded daily during her life. Daily age-specific survival $\left(\mathrm{l}_{\mathrm{x}}\right)$ and fecundity $\left(\mathrm{m}_{\mathrm{x}}\right)$ rates were calculated with the method identified for each eggplant cultivar by Birch (1948) by using RmStat-3 software (Ozgokce \& Karaca 2010). The net reproductive rate $\left(\mathrm{R}_{0}\right)$, the mean generation time $(\mathrm{T})$, the finite rate of increase $(\lambda)$ and the doubling time (DT) were calculated based on Birch (1948) method by using RmStat-3 software (Ozgokce \& Karaca 2010).

\section{Statistical analysis}

Some biological data (development and ovipoisition durations, fecundity, longevity, life table parameters) were compared among the seven eggplant cultivars with one-way analysis of variance (ANOVA) analysis followed by Tukey's multiple comparison tests using the statistical software SPSS 23. Differences of adult development in terms of gender were determined with two-way ANOVA using SPSS 23. Hatch and survival rates were compared with chi-square test by software SPSS 23. The bootstrap technique was used to estimate the means, variances and standard errors of the population parameters $\left(\mathrm{r}_{\mathrm{m}}, \mathrm{R}_{0}\right.$ and $\left.\mathrm{T}\right)$ by software SPSS 23 . To generate variable results, it was used for 1,000 replications using this method (Efron and Tibshirani 1993). The normality of the pseudovalues was tested with the Shapiro-Wilk test using software SPSS 23. Non-normality data was log-transformed, before subjected to the one-way ANOVA.

\section{Results}

\section{Survival and Development}

Tetranychus urticae successfully developed on all experimental eggplant cultivars at 16L:8D photoperiod at $27 \pm 1^{\circ} \mathrm{C}, 65 \pm 5 \% \mathrm{RH}$ and survival rates of immatures are given in Table 1 . Although the survival rate of T. urticae was varied from 55.51 on Anamur to 83.52 on Kemer, the differences were not significant (Table 1). The total developmental time was 9.16 to 11.47 days for females and 7.67 to 10.12 days for males feeding on the seven eggplant cultivars (Table 2). Developmental times of egg $\left(F_{6,539}=45.49 ; P<0.01\right)$ and all mobile juvenile stages (larva $F_{6,495}=7.72$, protonymph $P<0.01 F_{6,465}=21.73 ; P<0.01$, deutonymph $F_{6,406}=10.18$; $P<0.01)$ were affected by the eggplant cultivar. Additionally, significant differences were observed for the total development time of $T$. urticae feeding on different eggplant cultivars $\left(F_{13,460}=21.51 ; P<0.01\right)$. The development times were significantly longer on the Pala 49 cultivar and shorter on the Aydin siyahi, Topan 374 and Yalova Topan cultivars for both male and female development. In terms of two-way ANOVA, both gender and cultivar effects were found to be significant (cultivar $F_{6,6}=20.51 ; P<0.01$; gender $F_{1,1}=23.39 ; P<0.01$; cultivar x gender $\left.F_{6,6}=3.70 ; P<0.01\right)$.

\section{Adult longevity and Oviposition}

The female longevity of adult $T$. urticae was significantly different on tested cultivars $\left(\mathrm{F}_{6,71}=\right.$ $5.51 ; \mathrm{P}<0.01)$. But a significant difference was not observed in the value of fecundity $\left(F_{6,71}=\right.$ $1.74 ; P=0.125)$ (Table 3$)$. The female mites lived longer on Aydin siyahi cultivar (20.62 days) followed by Topan 374 (20.38 days) compared with just Yalova Topan and Anamur cultivars. There was no significant differences between the five cultivars except for Yalova Topan and Anamur cultivars. Except postoviposition period, the preoviposition and oviposition durations 
Table 1 Hatchability and survival rate of immature stages of Tetranychus urticae on different eggplant cultivars.

\begin{tabular}{lcccccc}
\hline \multicolumn{1}{c}{ Stages } & n & $\begin{array}{c}\text { Hatchability } \\
(\%)\end{array}$ & $\begin{array}{c}\text { Survival rate in } \\
\text { larvae (\%) }\end{array}$ & $\begin{array}{c}\text { Survival rate in } \\
\text { protonymph (\%) }\end{array}$ & $\begin{array}{c}\text { Survival rate in } \\
\text { deutonymph (\%) }\end{array}$ & $\begin{array}{c}\text { Survival rate (egg to } \\
\text { adult) }(\%)\end{array}$ \\
Cultivars & 107 & 83.70 & 89.47 & 85.88 & 86.30 & 55.51 \\
\hline Anamur & 106 & 91.51 & 86.59 & 91.67 & 97.41 & 70.75 \\
Aydin Siyahi & 65 & 81.54 & 84.91 & 86.67 & 94.87 & 56.92 \\
Balikesir 76 & 91 & 93.41 & 94.12 & 95.00 & 97.38 & 83.52 \\
Kemer & 77 & 81.82 & 92.06 & 75.86 & 94.55 & 71.43 \\
Pala 49 & 82 & 86.81 & 81.18 & 82.50 & 72.09 & 75.61 \\
Topan 374 & 116 & 94.83 & 88.18 & 82.47 & 96.25 & 66.38 \\
Yalova Topan & & 2.13 & 1.30 & 2.81 & 5.95 & 8.77 \\
\hline$X^{2}(d f=6)$ & 0.907 & 0.972 & 0.832 & 0.429 & 0.187 \\
$P$ & & & & &
\end{tabular}

of varied significantly among the eggplant cultivars (preoviposition $F_{6,71}=3.13 ; P<0.01$, oviposition $F_{6,71}=4.10 ; P<0.01$, postoviposition $F_{6,71}=0.56 ; P=0.76$ ) (Table 3). Similarly, the oviposition period of Yalova Topan was significantly lower (9.42 days) than other cultivars. But, no significant differences among oviposition period on Yalova Topan, Anamur, Kemer and Pala 49 cultivars were determined. Although the longest oviposition period was observed on Aydin siyahi (16.85 days), Balikesir 76 (16.60 days) and Topan 374 (16.15 days) cultivars, there are no significant effects on the other cultivars except for Yalova Topan. The age-specific survival rate $\left(1_{\mathrm{x}}\right)$ and fecundity $\left(\mathrm{m}_{\mathrm{x}}\right)$ curves of $T$. urticae on different eggplant cultivars are given in Figure 1.

The curves of age specific survival rate revealed that longevity of $T$. urticae is shortened depending on eggplant cultivars. Female longevity in Aydin Siyahi, Balikesir 76, Kemer and Topan 374 cultivars was much longer than other cultivars, Anamur, Pala-49 and Yalova Topan. The curves of age specific fecundity showed that oviposition pattern varied among the eggplant cultivars, however, T. urticae females gave the maximum amount of female individuals between the $13^{\text {th }}$ and $16^{\text {th }}$ days in all cultivars. The females began to oviposit on the $9^{\text {th }}$ or $10^{\text {th }}$ days in all cultivars and terminated until the $24^{\text {th }}-28^{\text {th }}$ days for Anamur, Pala- 49 and Yalova Topan, the

Table 2 Mean $( \pm$ SE) developmental time (days) of Tetranychus urticae on different eggplant cultivars.

\begin{tabular}{lcccccc}
\hline \multicolumn{1}{c}{ Stages } & Egg & Larva & Protonymph & Deutonymph & $\begin{array}{c}\text { Total } \\
\text { development }\end{array}$ & $\begin{array}{c}\text { Total } \\
\text { development } \hat{\sigma}\end{array}$ \\
Cultivars & & & & & & \\
\hline Anamur & $3.09 \pm 0.04 \mathrm{c}$ & $2.12 \pm 0.03 \mathrm{a}$ & $2.20 \pm 0.04 \mathrm{a}$ & $2.09 \pm 0.07 \mathrm{bc}$ & $9.83 \pm 0.05 \mathrm{bc}$ & $8.97 \pm 0.03 \mathrm{def}$ \\
Aydin Siyahi & $3.29 \pm 0.05 \mathrm{c}$ & $1.75 \pm 0.05 \mathrm{bc}$ & $1.55 \pm 0.06 \mathrm{~cd}$ & $1.91 \pm 0.05 \mathrm{~cd}$ & $9.16 \pm 0.12 \mathrm{de}$ & $8.54 \pm 0.15 \mathrm{efg}$ \\
Balikesir 76 & $3.79 \pm 0.12 \mathrm{~b}$ & $1.84 \pm 0.09 \mathrm{abc}$ & $1.93 \pm 0.09 \mathrm{ab}$ & $2.33 \pm 0.12 \mathrm{abc}$ & $10.31 \pm 0.31 \mathrm{~b}$ & $9.85 \pm 0.36 \mathrm{bc}$ \\
Kemer & $3.75 \pm 0.07 \mathrm{~b}$ & $1.74 \pm 0.08 \mathrm{bc}$ & $2.00 \pm 0.07 \mathrm{ab}$ & $1.88 \pm 0.09 \mathrm{~cd}$ & $10.09 \pm 0.18 \mathrm{~b}$ & $8.57 \pm 0.15 \mathrm{ef}$ \\
Pala 49 & $4.39 \pm 0.09 \mathrm{a}$ & $2.02 \pm 0.15 \mathrm{ab}$ & $2.15 \pm 0.12 \mathrm{a}$ & $2.64 \pm 0.23 \mathrm{a}$ & $11.47 \pm 0.35 \mathrm{a}$ & $10.12 \pm 0.27 \mathrm{bc}$ \\
Topan 374 & $3.66 \pm 0.06 \mathrm{~b}$ & $1.54 \pm 0.06 \mathrm{c}$ & $1.40 \pm 0.07 \mathrm{~d}$ & $2.33 \pm 0.09 \mathrm{ab}$ & $9.43 \pm 0.15 \mathrm{~cd}$ & $7.67 \pm 0.18 \mathrm{~g}$ \\
Yalova Topan & $3.70 \pm 0.05 \mathrm{~b}$ & $1.92 \pm 0.06 \mathrm{ab}$ & $1.76 \pm 0.06 \mathrm{bc}$ & $1.59 \pm 0.09 \mathrm{~d}$ & $9.18 \pm 0.12 \mathrm{de}$ & $8.41 \pm 0.15 \mathrm{fg}$ \\
\hline
\end{tabular}

* Means followed by the same letter in a column are not significantly different (Tukey, $\mathrm{P}<0.05)$. 

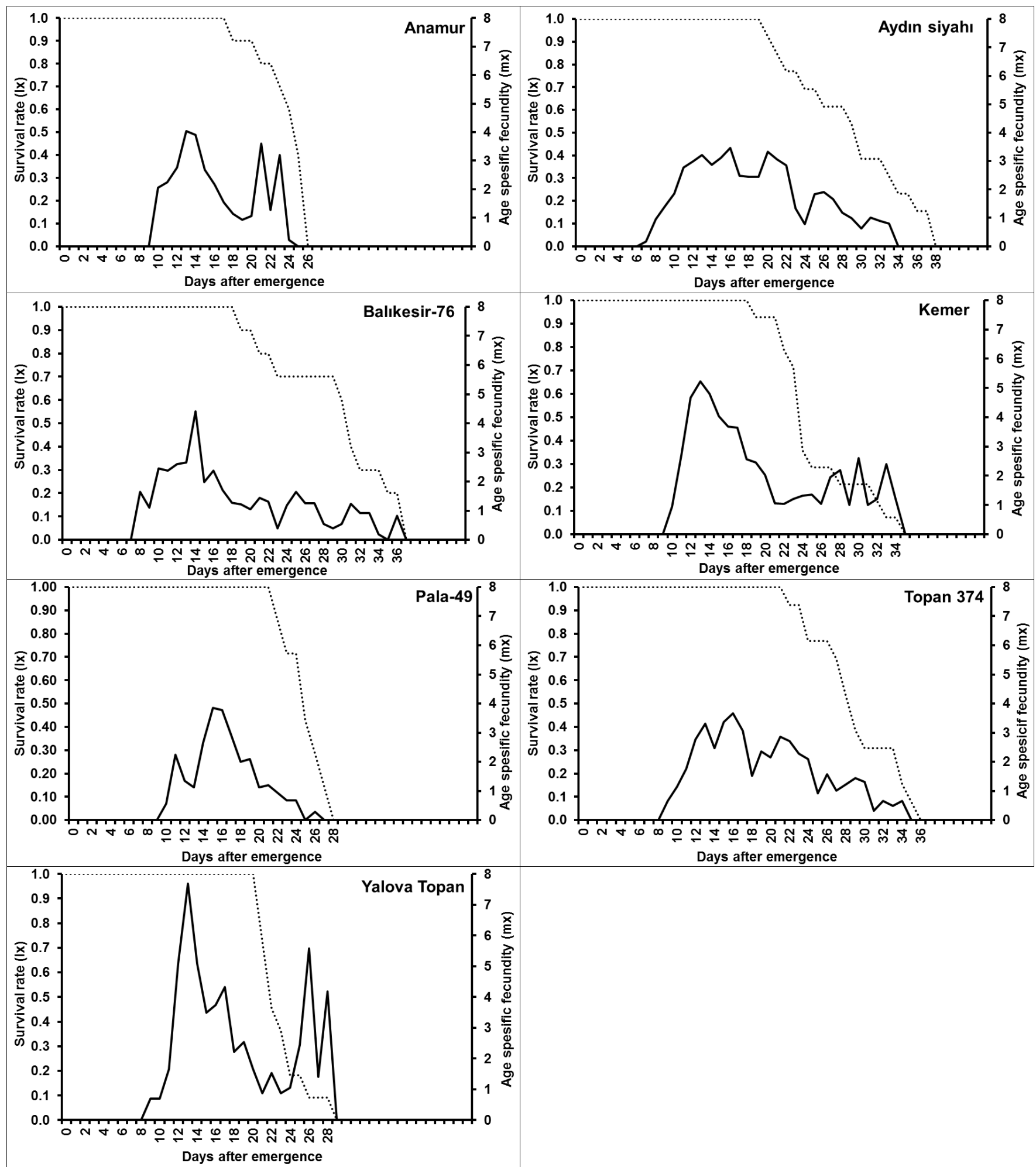

Figure 1 Age-specific survival rate (1 $)$, age-specific fecundity rate $\left(\mathrm{m}_{\mathrm{x}}\right)$ and $\mathrm{l}_{\mathrm{x}} \mathrm{m}_{\mathrm{x}}$ curves in Tetranychus urticae on different eggplant cultivars $1_{x}=($ egg hatchability)*(proportion of females alive at age $\mathrm{x}), \mathrm{m}_{\mathrm{x}}=$ (proportion of females)*(age-specific oviposition). 
Table 3 Mean ( \pm SE) daily egg production, oviposition duration and adult female longevity (days) of Tetranychus urticae on different eggplant cultivars.

\begin{tabular}{lccccc}
\hline Stages & $\begin{array}{c}\text { Adult female } \\
\text { longevity (days) }\end{array}$ & $\begin{array}{c}\text { Preoviposition } \\
\text { (days) }\end{array}$ & $\begin{array}{c}\text { Oviposition } \\
\text { (days) }\end{array}$ & $\begin{array}{c}\text { Postoviposition } \\
\text { (days) }\end{array}$ & $\begin{array}{c}\text { Total number of } \\
\text { eggs/female }\end{array}$ \\
\hline Cultivars & $14.00 \pm 0.76 \mathrm{bc}$ & $1.30 \pm 0.15 \mathrm{ab}$ & $12.20 \pm 0.77 \mathrm{ab}$ & $1.60 \pm 0.16 \mathrm{a}$ & $45.50 \pm 6.28 \mathrm{a}$ \\
Anamur & $20.62 \pm 1.56 \mathrm{a}$ & $1.31 \pm 0.18 \mathrm{ab}$ & $16.85 \pm 1.31 \mathrm{a}$ & $2.46 \pm 0.42 \mathrm{a}$ & $69.69 \pm 4.97 \mathrm{a}$ \\
Balikesir 76 & $19.40 \pm 2.03 \mathrm{abc}$ & $1.00 \pm 0.21 \mathrm{~b}$ & $16.60 \pm 2.31 \mathrm{a}$ & $2.30 \pm 0.89 \mathrm{a}$ & $58.60 \pm 8.46 \mathrm{a}$ \\
Kemer & $16.14 \pm 1.30 \mathrm{abc}$ & $0.93 \pm 0.07 \mathrm{~b}$ & $12.64 \pm 1.49 \mathrm{ab}$ & $2.50 \pm 0.44 \mathrm{a}$ & $71.14 \pm 7.37 \mathrm{a}$ \\
Pala 49 & $14.33 \pm 1.02 \mathrm{abc}$ & $1.17 \pm 0.31 \mathrm{ab}$ & $11.83 \pm 1.35 \mathrm{ab}$ & $1.50 \pm 0.96 \mathrm{a}$ & $48.17 \pm 4.19 \mathrm{a}$ \\
Topan 374 & $20.38 \pm 1.38 \mathrm{a}$ & $1.84 \pm 0.25 \mathrm{a}$ & $16.15 \pm 1.34 \mathrm{a}$ & $2.39 \pm 0.49 \mathrm{a}$ & $63.92 \pm 7.77 \mathrm{a}$ \\
Yalova Topan & $13.17 \pm 0.64 \mathrm{c}$ & $1.16 \pm 0.11 \mathrm{ab}$ & $9.42 \pm 0.87 \mathrm{~b}$ & $2.58 \pm 0.39 \mathrm{a}$ & $55.50 \pm 8.47 \mathrm{a}$ \\
\hline
\end{tabular}

* Means followed by the same letter in a column are not significantly different (Tukey, $\mathrm{P}<0.05$ ).

$34^{\text {th }}-35^{\text {th }}$ days for Aydin Siyahi, Balikesir 76 , Kemer and Topan 374.

\section{Life table parameters}

The values of life table parameters of T. urticae on the seven eggplant cultivars are shown in Table 4. The most important parameters, $\mathrm{r}_{\mathrm{m}}, \mathrm{R}_{0}$ and $\mathrm{T}$, of T. urticae differed between the eggplant cultivars $\left(\mathrm{r}_{\mathrm{m}} F_{6,56}=22.82 ; P<0.01, \mathrm{R}_{0} F_{6,56}=237.92 ; P<0.01\right.$, $\mathrm{T} F_{6,56}=2.52 ; P=$ $0.03)$. The $\mathrm{r}_{\mathrm{m}}$ value of T. urticae was significantly the lowest for Pala $49(0.218)$ followed by Anamur (0.242) and Topan 374 (0.242). The highest $r_{m}$ value of the spider mite was found in the other cultivars, Aydin Siyahı, Balikesir 76, Yalova Topan and Kemer. Similarly, $\mathrm{R}_{0}$ value was significantly lowest for Pala 49 (26.74) and Anamur (30.46) cultivars. The significant highest $\mathrm{R}_{0}$ value of T. urticae was determined in Aydin Siyahi cultivar (45.51). Differently, the T value of T. urticae for Balikesir 76 and Yalova Topan was significantly the lowest (13.31 and 14.11, respectively) followed by Anamur, Aydin Siyahı and Kemer. The GRR of the mite showed similar results of its $\mathrm{R}_{0}$. The shortest doubling time (D) was found for Aydin Siyahi, Balikesir 76, Kemer and Yalova Topan cultivars. The $\lambda$ value of T. urticae exhibited similar to its $\mathrm{D}$ value for all eggplant cultivars.

Table 4 Life table parameters of population growth in Tetranychus urticae on different eggplant cultivars.

\begin{tabular}{|c|c|c|c|c|c|c|}
\hline Parameters & $\begin{array}{l}\text { Intrinsic rate of } \\
\text { natural increase } \\
\qquad\left(\mathrm{r}_{\mathrm{m}}\right)\end{array}$ & $\begin{array}{l}\text { Net reproductive rate (R0) } \\
\text { (female/female/generation) }\end{array}$ & $\begin{array}{c}\text { Mean } \\
\text { generation } \\
\text { time in days }\end{array}$ & $\begin{array}{c}\text { Gross reproduction rate } \\
\text { (GRR) (female egg/ } \\
\text { female/generation) }\end{array}$ & $\begin{array}{l}\text { Doubling } \\
\text { time (D) } \\
\text { days }\end{array}$ & $\begin{array}{l}\text { Finite rate of increase }(\lambda) \\
\text { (individual/female/day) }\end{array}$ \\
\hline \multicolumn{7}{|l|}{ Cultivars } \\
\hline Anamur & $0.242 b$ & $30.46 \mathrm{~d}$ & $14.13 c$ & 32.79 & 2.87 & 1.274 \\
\hline Aydin Siyahi & $0.269 a$ & $45.51 \mathrm{a}$ & $14.15 c$ & 52.36 & 2.57 & 1.31 \\
\hline Balikesir 76 & $0.267 a$ & $35.11 \mathrm{c}$ & $13.31 d$ & 40.94 & 2.59 & 1.307 \\
\hline Kemer & $0.259 a$ & $42.69 b$ & $14.52 \mathrm{c}$ & 57.32 & 2.68 & 1.295 \\
\hline Pala 49 & $0.218 \mathrm{c}$ & $26.74 \mathrm{e}$ & $15.06 b$ & 27.46 & 3.18 & 1.244 \\
\hline Topan 374 & $0.242 b$ & $42.09 b$ & $15.45 a$ & 47.76 & 2.86 & 1.274 \\
\hline Yalova Topan & $0.265 a$ & $42.15 b$ & $14.11 \mathrm{bcd}$ & 56.79 & 2.62 & 1.304 \\
\hline
\end{tabular}

* Means followed by the same letter in a column are not significantly different (Tukey, $\mathrm{P}<0.05$ ). 


\section{Discussion}

The present study indicated that eggplants are one of the favourable hosts for T. urticae, allowing shorter development durations of the immature stages. The development of the mite completed in 7.7-10.1 days for males and 9.2-11.5 days for females. The immature developmental time was very similar with the values (9.1-11.2) reported by Khanamani et al. (2013) on seven Indian eggplant cultivars. In addition, these durations are very close with previous studies performed on different suitable hosts in the same climatic condition: sweet pepper (11.7 days), cucumber (10.4 days), bean (10.9 days) and tomato (11.6 days) plants (Zatyko \& Martinovich 1986; Kasap 2002; Razmjou et al. 2009; Atalay \& Kumral 2013; Kumral et al. 2017). In the current study, a remarkable result is that the development durations of some eggplant cultivars are very close to bean values which are the most suitable host for T. urticae (Kasap 2002). This result is consistent with Van Den Boom et al. (2004) and suggests that eggplants have got a weak direct defense level against $T$. urticae due to poor defensive content of the host plant. In addition, compared with all experimental eggplant cultivars in this study, the lower immature development durations of the spider mite was determined in some eggplant cultivars: Aydin Siyahı, Yalova Topan and Topan 374. A faster developmental time of an arthropod species on its host indicates higher susceptibility of the host plant (Golizadeh et al. 2017). The other important factor that affects population growth of a spider mite is survival rates on its host plant (Crooker, 1985). In the present study, although high survivality rates were observed in some eggplant cultivars, Aydin Siyahi, Kemer, Pala 49 and Topan 374, the differences were not statistically significant.

It is well known that the host plant quality can affect fecundity rate of their herbivore (Price et al. 1980). In the current study, the oviposition period was found as 9.42-16.85 days and the number of eggs per female was 45.50-71.14. These durations and values were determined as 5-13 days and 85-276 eggs for tomato; 24 days and 231 eggs for bean; 19 days and 124 eggs for soybean; 21 days and 172 eggs in cucumber; 7-13 days and 22-56 eggs for sweet pepper plants (Kasap 2002, Dehghan et al. 2009, Razmjou et al. 2009, Atalay \& Kumral 2013; Kumral et al. 2017). Compared the most favourable host plants, i.e. beans and cucumbers, the oviposition durations of T. urticae on our eggplant cultivars were found to be very similar, but its fecundity rate was found to be lower than the host plants. Similarly, the results of Khanamani et al. (2013) showed that $T$. urticae females can survive for a very long duration (17.8-19.1 days) on Indian eggplant cultivars, but the reproductivity is lower (5.25-29.23 eggs/female) compared with the most preferred host plants. Our results conform to the longevity results of Khanamani et al. (2013) that T. urticae feed on seven Indian eggplant cultivars. Differently, T. urticae females that fed on Aydin Siyahi, Kemer and Topan 374 cultivars showed the highest fecundity rates in our study, but the differences among the cultivars were not statistically significant.

Some biodemographic parameters can be shown in the population growth potential of any pest on its hostplant (Birch 1948). In the present study, the $\mathrm{r}_{\mathrm{m}}$ and $\mathrm{R}_{\mathrm{o}}$ values of T. urticae that fed on the seven eggplant cultivars were found as $0.218-0.269$ and $26.47-45.51$. These values were much greater than the findings of Khanamani et al. (2013) when T. urticae females reared on Indian eggplant cultivars (0.031-0.157 and 1.5-11.6). On the other hand, our $\mathrm{r}_{\mathrm{m}}$ values were very close compared with the results on the most favourable host plants beans $(0.27)$, soybeans (0.26) and tomatoes (0.26-0.29) (Kasap 2002; Dehghan et al. 2009; Atalay \& Kumral 2013). The $\mathrm{r}_{\mathrm{m}}$ value of T. urticae varies between 0.22 and 0.34 in the optimum conditions and host plants conditions as reported by Sabelis (1985). Because fewer females for each generation are produced by $T$. urticae females feed on the seven eggplant cultivars, the $\mathrm{R}_{\mathrm{o}}$ values were found to be much less than the favourable host plants i.e. beans (185.4), soybeans (59-66) and tomatoes (49-131) (Kasap 2002; Dehghan et al. 2009; Atalay \& Kumral 2013; Najafabadi et al. 2014). In addition, both the $\mathrm{r}_{\mathrm{m}}$ and Ro values of $T$. urticae were found to be significantly higher in Aydin Siyahi and Kemer, Topan 374 and Yalova Topan cultivars compared with the values of the other cultivars. This difference between the cultivars is likely related to the lack of nutrients that are effective in fecundity of the mite (Van Den Boom et al. 2004). As reported 
by Crooker (1985), host plant nitrogen content is associated with increases in spider mite populations, often through effects on fecundity. Because the chemical and nutritient contents of the seven eggplant cultivars are not known, it is not possible to explain the reasons with the findings of this study.

Considering the results of these lifetable parameters, eggplants can be regarded as a less suitable host plant compared to beans and soybeans in accordance with the findings of Van Den Boom et al. $(2003 ; 2004)$. But, eggplants are very much preferred by T. urticae due to its weak direct defense mechanism against T. urticae as indicated by the researchers. However, when compared to other resistant eggplant cultivars (Khanamani et al. 2013), it is not possible to declare that any Turkish eggplant cultivar tested in this study (i.e. Anamur, Pala 49 and Balikesir 76) is resistant to T. urticae. But, the four (Aydin Siyahi and Kemer, Topan 374 and Yalova Topan) have been found to be potentially susceptible cultivars to T. urticae because they have got high population growth parameters which are very close to their most favourable plant species.

\section{Acknowledgements}

This study was supported by Uludag University, Scientific Research Unit, Bursa, Turkey, Grant OUAP(Z)-2013/32. Also, we thank the undergraduate students, Gamze Bülbül and Betül Güven, for helping us during some biological tests.

\section{References}

Atalay E., Kumral N.A. 2013. Biolocigal features and life tables of Tetranychus urticae (Koch) (Acari: Tetranycidae) on different table tomato varieties. Türkiye Entomoloji Dergisi, 37: 329-341.

Birch L.C. 1948. The intrinsic rate of natural increase of an insect population. Journal of Animal Ecology, 17: 15-26. doi:10.2307/1605

Brar B., Manmeet K., Ghai J. 2003. Seasonal abundance of phytophagous and predatory mites infesting brinjal in Punjab. Annals of Biology (Hissar), 19(2): 231-234.

Can M., Cobanoglu S. 2010. Studies on the determination of mite (Acari) species and their hosts of greenhouse vegetables in Kumluca, Antalya. Akdeniz Üniversitesi Ziraat Fakültesi Dergisi, 23(2) $87-92$.

Crooker A. 1985. Embryonic and Juvenile Development. In: Helle W, Sabelis MV, editors. Spider mites: their biology, natural enemies and control. Amsterdam: Elsevier, 149-163pp.

Dehghan M.S., Allahyari H., Saboori A., Nowzari J., Naveh V.H. 2009. Fitness of Tetranychus urticae Koch (Acari: Tetranychidae) on different soybean cultivars: biology and fertility life-tables. International Journal of Acarology, 35: 341-347. doi:10.1080/01647950903074733

Efron B, Tibshirani R.J. 1993. An introduction to the bootstrap. New York, NY: Chapman and Hall; 436p.

Golizadeh A., Ghavidel S., Razmjou J., Fathi S.A.A., Hassanpour M. 2017. Comparative life table analysis of Tetranychus urticae Koch (Acari: Tetranychidae) on ten rose cultivars. Acarologia, 57(3): 607-616.

Grbić M., Van Leeuwen T., Clark R.M, Rombauts S., Rouzé P., Grbić V., Osborne E.J. 2011.The genome of Tetranychus urticae reveals herbivorous pest adaptations. Nature, 479 (7374): 487-492. doi:10.1038/nature10640

Grewal J.S. 1992. Seasonal fluctuation in the populations of various mite species associated with brinjal crop in Punjab. Annals of Entomology, 10(1): 37-40.

Hoy M.A. 2011. Agricultural Acarology. Introduction to Integreated Mite Management. CRC Press Taylor \& Francis Group, New York, 410p. doi:10.1201/b10909

Kapoor V.C., Paul M., Kapur J. 1997. Seasonal incidence of mite species infesting okra (Hibiscus esculentus) and brinjal (Solanum melongena) in Punjab. Indian Journal of Agricultural Sciences, 67(7): 325-326.

Kasap I. 2002. Biology and life tables of the twospotted spider mite, Tetranychus urticae Koch (Acari: Tetranychidae) on three different host plants in laboratory conditions. Türkiye Entomoloji Dergisi, 26(4): 257-266.

Keskin N., Kumral N.A. 2015. Screening tomato varietal resistance against the two-spotted spider mite [Tetranychus urticae (Koch)]. International Journal of Acarology, 41(4): 300-309. doi: 10.1080/01647954.2015.1028440

Khanamani M., Fathipour Y., Hajiqanbar, H. 2013. Population growth response of Tetranychus urticae to eggplant quality: application of female age-specific and age-stage, two-sex life tables. International Journal of Acarology, 39(8): 638-648. doi:10.1080/01647954.2013.861867

Kilincer N., Yiğit A., Kazak C., Er M.K., Kurtulus A., Uygun N. 2010. Biological control of pests from theory to practice. Türkiye Biyolojik Mücadele Dergisi, 1(1): 15-60. 
Kumral N.A., Kovanci B. 2005. Seasonal population dynamics of the Two-spotted spider mite, Tetranychus urticae Koch (Acari: Tetranychidae) under acaricide constraint on eggplant in Bursa province. Acarologia, 45(4): 297-303.

Kumral N.A., Cobanoglu S. 2016. The Mite (Acari) biodiversity and population fluctuation of predominat species in eggplant. Tarim Bilimleri Dergisi-Journal of Agricultural Sciences, 22(2): 261-274.

Kumral N.A., Goksel P.H., Aysan E., Kolcu A. 2017. Biological parameters and population development of Tetranychus urticae Koch, 1836 (Acari: Tetranychidae) on different pepper cultivars. Türkiye Entomoloji Dergisi, 41(3): 263-273. doi:10.16970/entoted.297132

Leite G.L.D., Picanco M., Zanuncio J.C., Marquini F. 2003. Factors affecting mite herbivory on eggplants in Brazil. Experimental and Applied Acarology, 31(3-4): 243-252. doi:10.1023/B:APPA.0000010379. 05878.20

Migeon A., Dorkeld F. 2016. Spider Mites Web: a Comprehensive Database for the Tetranychidae. http://www.montpellier.inra.fr/CBGP/spmweb.

Moon H., Lim J., Kim J., Ryu J., Ko B., Kim D., Hwang C. 2006. Biological control of Tetranychus urticae by Phytoseiulus persimilis in eggplant greenhouses. Korean Journal of Applied Entomology, 45(2): 173-177.

Najafabadi S.S.M., Shoushtari R.V., Zamani A.A., Arbabi M., Farazmand H. 2014. Life parameters of Tetranychus urticae (Acari: Tetranychidae) on six common bean cultivars. Journal of Economic Entomology, 107: 614-622. doi:10.1603/EC11205

Ozgokce M.S., Karaca İ. 2010. Yaşam Çizelgesi: Temel Prensipler ve Uygulamalar. Türkiye Entomoloji Derneği 1. Çalıştayı, Ekoloji Çalışma Grubu, Isparta.

Ozsisli T., Cobanoglu S. 2011. Mite (Acari) fauna of some cultivated plants from Kahramanmaras, Turkey. African Journal of Biotechnology, 10(11): 2149-2155.

Price P.W., Bouton C.E., Gross P., McPheron B.A., Thompson J.N., Weis A.E. 1980. Interactions among three trophic levels: influence of plants on interactions between insect herbivores and natural enemies. Annual Review of Ecology and Systematics, 11(1): 41-65. doi:10.1146/annurev.es.11.110180.000353

Reddy G.V.P., Kikuchi R., Remolona J.E. 2011. New mite species associated with certain plant species from Guam. Journal of Entomological and Acarological Research, 43(1): 41-46. doi: 10.4081/jear.2011.41

Razmjou J., Tavakkoli H., Fallahi A. 2009. Effect of soybean cultivar on life history parameters of Tetranychus urticae Koch (Acari: Tetranychidae). Journal of Pest Science, 82(1): 89-94. doi:10.1007/s10340-008-0227-8

Sabelis MW. 1985. Reproductive strategies. In: Helle W, Sabelis MV, editors. Spider mites: their biology, natural enemies and control. Amsterdam: Elsevier, 265-279pp.

Sedaratian A., Fathipour Y., Moharramipour S. 2011. Comparative life table analysis of Tetranychus urticae (Acari: Tetranychidae) on 14 soybean genotypes. Insect Science, 18: 541-553. doi:10.1111/j. 1744-7917.2010.01379.x

Shibao M., Momoshita M., Yamanaka S., Tanaka H. 2009. Control of melon thrips, Thrips palmi Karny on greenhouse eggplant by releasing of Amblyseius swirskii Athias-Henriot. Annual Report of the Kansai Plant Protection Society, 52: 21-25 doi:10.4165/kapps.52.21

Singh M.P., Singh K.M. 1999. Some phytophagous and predaceous mites associated with summer vegetables in Manipur. Insect Environment, 4(4): 117.

Simon J.Y. 2014. The toxicology and biochemistry of insecticides. CRC press, 353p.

Soysal A., Yayla A. 1988. Preliminary studies on the population density of Tetranychus spp. (Acarina: Tetranychidae), harmful on vegetable crops and their natural enemies in Antalya. Bitki Koruma Bülteni, 28(1-2): 29-41.

Stansly P.A., Castillo J., Casta-é C., Perdikis D. 2009. Control of broad mite, Polyphagotarsonemus latus and the whitefly Bemisia tabaci in open field pepper and eggplant with predaceous mites. IOBC/WPRS Bulletin, 49: 145-152.

Tomczyk A., Kropczynska D. 1985. Effects on the Host Plant. In: Helle W, Sabelis MV, editors. Spider mites: their biology, natural enemies and control. Amsterdam: Elsevier, 317-331pp.

Van Den Boom C.E.M., Van Beek T.A., Dicke M. 2003. Differences among plant species in acceptance by the spider mite Tetranychus urticae Koch. Journal of Appllied Entomology, 127: 177-183. doi:10.1046/j.1439-0418.2003.00726.x

Van Den Boom C.E.M., Van Beek T.A., Posthumus M.A., De Groot A., Dicke M. 2004. Qualitative and quantitative variation among volatile profiles induced by Tetranychus urticae feeding on plants from various families. Journal of Chemical Ecology, 30: 69-89. doi:10.1023/B:JOEC.0000013183.72915.99

Van Leeuwen T., Vontas J., Tsagkarakou A., Dermauwa W., Tirry L. 2010. Acaricide resistance mechanisms in the two-spotted spider mite Tetranychus urticae and other important Acari: a review. Insect Biochemistry and Molecular Biology, 40: 563-572. doi:10.1016/j.ibmb.2010.05.008

Whalon M.E., Mota-Sanchez R.M., Hollingworth R.M., Duynslager L. 2016. Artrhopods Resistant to Pesticides Database (ARPD). http://www. pesticideresistance.org.

Zatyko L., Martinovich V. 1986. Resistance to the red spider mite (Tetranychus urticae Koch) in the "Fehérözön Synthetic" pepper variety. VIth meeting on genetics and breeding on Capsicum and eggplant, Zaragoza (Spain), October 21-24, 1986, pp. 125-128. 